\title{
Water temperature and riverine ecosystems: An overview of knowledge and approaches for assessing biotic responses, with special reference to South Africa
}

\author{
Helen Dallas* \\ Freshwater Research Unit, Department of Zoology, University of Cape Town, Private Bag X3, Rondebosch 7700, South Africa
}

\begin{abstract}
Available information pertaining to water temperature in riverine ecosystems is examined and consolidated into an overview that describes the spatial and temporal variation in water temperature, the importance of water temperature in lotic ecosystems, the measurement and modelling of water temperature, anthropogenic factors that modify water temperature, the effects of temperature changes on the physical and chemical characteristics of water; and on aquatic organisms and ecosystems. Methods for assessing the effects of temperature changes on aquatic organisms are discussed and current water temperature guidelines for the protection of aquatic ecosystems are outlined. This paper highlights the complexity of water temperature in the aquatic environment and the importance of understanding the spatio-temporal variability in water temperature and the variable responses of aquatic organisms to thermal stress. Anthropogenic modifiers of the thermal regime, which include heated discharges, flow modifications, riparian vegetation removal and global climate change; present ongoing threats to aquatic ecosystems. Whilst Northern Hemisphere information on water temperature is plentiful, this overview has identified the huge gap that exists in temperature-related data in South Africa. Without baseline data on water temperature and the thermal requirements of aquatic organisms, it is extremely difficult to adequately manage aquatic ecosystems. The risk of increasingly harsh conditions caused by greater water demands and climate change accentuates the need for a greater understanding of the thermal conditions in aquatic ecosystems in South Africa and the requirements and triggers of the associated aquatic biota. Future directions for thermal research are described.
\end{abstract}

Keywords: water temperature, riverine ecosystems, rivers, thermal regimes, biotic responses, aquatic organisms

\section{Introduction}

Natural thermal characteristics of riverine ecosystems are dependent on hydrological (e.g. source of water, relative contribution of groundwater, rate of flow or discharge, volume of water, inflow from tributaries); regional (e.g. latitude, altitude); climatological (e.g. air temperature, solar radiation, cloud cover, wind speed, vapour pressure, precipitation, evaporation); and structural features (e.g. topographic features, aspect and slope, riparian vegetation cover, channel form, geology, substratum, water depth, turbidity, percentage of pool habitat) of the region, catchment and site (Fig. 1). The relative importance of these features differs amongst rivers and river reaches.

\section{Spatial and temporal variation in water temperature}

At the catchment scale, differences are driven by variation in climate, geography, topography and vegetation (Poole et al., 2001). At a river scale, variation occurs longitudinally down a river system with headwaters typically cooler than lowland areas. Maximum temperatures increase downstream (Ward, 1985), while the maximum range is often found in the middle reaches (Vannote and Sweeney, 1980). At a site scale, differences are often determined by geomorphic variation, i.e. laterally across the channel

\footnotetext{
* To whom all correspondence should be addressed.

푱 +2721 650-3631; fax: +2721 650-3301;

e-mail: Helen.Dallas@uct.ac.za

Received 22 June 2007; accepted in revised form 10 June 2008.
}

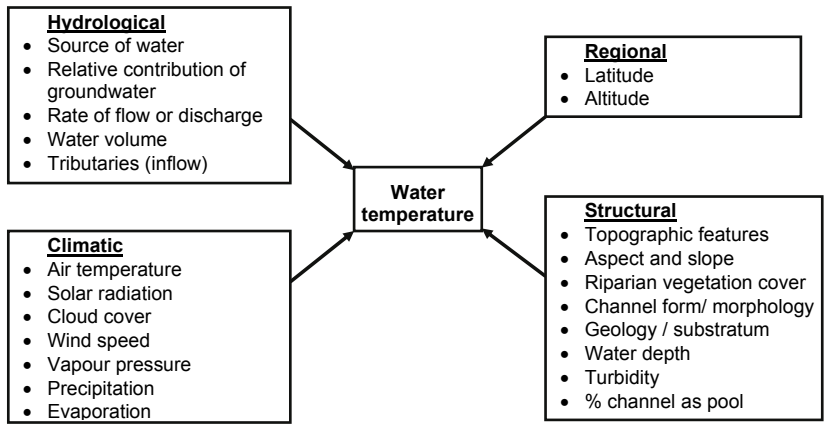

Figure 1

Hydrological, regional, climatic and structural factors influencing water temperature in riverine ecosystems

and in relation to different habitats (Ebersole et al., 2003; Poole et al., 2001), with different habitats having different temperature profiles (e.g. Appleton, 1976; Harrison and Elsworth, 1958; Allanson, 1961; Nordlie and Arthur, 1981).

Lotic systems in regions of seasonal climates exhibit diel (daily) and annual (seasonal) temperature periodicity patterns (Ward, 1985). Hourly temperatures are generally lowest during the night time or early morning and highest in the mid to late afternoon, although this may shift with season (e.g. Hopkins, 1971) and size of river. Small, heavily canopied streams and large, deep rivers exhibit the least diel ranges in water temperature, while shallow streams exposed to direct solar radiation and braided rivers exhibit the largest diel ranges in water temperature (Ward, 1985; Constantz et al., 1994). Seasonally, temperatures generally exhibit a sinusoidal pattern with temperatures highest 
- Water temperature in the Lang River, a shaded mountain stream in the Western Cape (King et al., 1988), varied from 7.5 to $15.1^{\circ} \mathrm{C}$, with a mean of $10.9^{\circ} \mathrm{C}$ at one site (altitude $=671 \mathrm{~m}$ ), and from 7.0 to $20.0^{\circ} \mathrm{C}$, with a mean of $13.1^{\circ} \mathrm{C}$ at a second site (altitude $=335 \mathrm{~m}$ ).

- Water temperature in the Molenaars River, an upper foothill river in the Western Cape, ranged from 7.9 to $28.4^{\circ} \mathrm{C}$, with a median temperature of $15.6^{\circ} \mathrm{C}$. Summer peaks occurred between mid- December to end of February although inter-annual variation was apparent (Unpublished data, GR Ractliffe, Freshwater Research Unit, University of Cape Town).

- Water temperatures, given as the winter minimum to summer maximum range per zone, for the Berg River in the Western Cape, were measured in the $1950 \mathrm{~s}$ (Harrison, 1965). Values per zone were: Mountain Torrent zone (8.9 to $22.8^{\circ} \mathrm{C}$ ), Upper Foothill $\left(9.0\right.$ to $\left.29^{\circ} \mathrm{C}\right)$, Lower foothill stony run zone $\left(9.0\right.$ to $\left.32.5^{\circ} \mathrm{C}\right)$, Foothill soft-bottom zone $\left(10.0\right.$ to $\left.31.7^{\circ} \mathrm{C}\right)$ and the Flood plain zone $\left(9.0\right.$ to $\left.25.5^{\circ} \mathrm{C}\right)$.

- The Buffalo River in the Eastern Cape had average minimum and maximum temperature ranges of 12 to $20^{\circ} \mathrm{C}$ in the Mountain Torrent Zone, 15 to $30^{\circ} \mathrm{C}$ in the Upper Foothill Zone, and 19 to $35^{\circ} \mathrm{C}$ in the Lower Foothill Zone (Palmer and O'Keeffe, 1989). In winter, the cold waters typical of the upper reaches, extended further downstream.

- Water temperatures (minimum and maximum) in the Umzimvubu $\left(4\right.$ to $\left.28^{\circ} \mathrm{C}\right), \operatorname{Umzintlava}\left(1\right.$ to $\left.27^{\circ} \mathrm{C}\right), \mathrm{Kinira}\left(9\right.$ to $\left.28^{\circ} \mathrm{C}\right)$, Tina $\left(12\right.$ to $\left.25^{\circ} \mathrm{C}\right)$ and Tsitsa $\left(11\right.$ to $23^{\circ} \mathrm{C}$ ) rivers in the Eastern Cape (Madikizela and Dye, 2003) were measured seasonally.

- Minimum and maximum daily means, measured in each season in the Gladdespruit Mpumalanga (Appleton, 1976), showed that minimum and maximum temperatures ranged from 15.2 to $29.3^{\circ} \mathrm{C}$, in summer 12.1 to $21.6^{\circ} \mathrm{C}$, in autumn 6.5 to $15.4^{\circ} \mathrm{C}$ in winter, and 12.2 to $21.1^{\circ} \mathrm{C}$ in spring.

- Mean and maximum water temperatures (summarised from daily water temperature) increased longitudinally down the Sabie River, Mpumalanga (Rivers-Moore et al., 2004) as did variability, with lowland reaches having a greater daily range than upper reaches. Variability varied with season, with greatest variability in winter (June to August). Minimum temperatures remained relatively constant. The average daily water temperatures could be divided into two clusters reflecting longitudinal distance: 0 to $57 \mathrm{~km}$ and 57 to $160 \mathrm{~km}$ which coincided with foothill and lowland zones.

- Instantaneous water temperature was measured at many sites in the Vaal Dam catchment, Free State (Chutter, 1970). Minimum and maximum temperatures for each zone were: Source Zone $\left(5.9\right.$ to $\left.27.0^{\circ} \mathrm{C}\right)$, Eroding Zone (7.0 to $\left.28.8^{\circ} \mathrm{C}\right)$, Stable Depositing Zone $\left(4.2\right.$ to $\left.24.4^{\circ} \mathrm{C}\right)$, Unstable Depositing Zone $\left(4.5\right.$ to $\left.28.2^{\circ} \mathrm{C}\right)$ and a High-lying Unstable Depositing Zone $\left(4.4\right.$ to $30.5^{\circ} \mathrm{C}$ ). Temperatures were lower in the Source Zone but mean temperatures in the remaining zones were relatively uniform. Diurnal ranges measured over two periods showed an April range of 15.0 to $21.6^{\circ} \mathrm{C}$ and September range of 13.5 to $18.2^{\circ} \mathrm{C}$.

- Fluctuations in Vaal River surface water temperature followed a seasonal pattern marked by rapid warming of the water during September October and November and rapid cooling during April May and June (Free State, Roos and Pieterse, 1994). The seasonal extremes were small in comparison to the air temperature fluctuations where monthly average was between -1.1 and $33^{\circ} \mathrm{C}$ whilst the difference in water temperature (midday) was between 10 and $27^{\circ} \mathrm{C}$. There was a lag of days to several weeks between water and air temperature.

- Studies undertaken in the 1960s and 1970s for many rivers in the KwaZulu-Natal region (e.g. Brand et al., 1967 Archibold et al., 1969) reported temperatures ranging from 7.5 to $35^{\circ} \mathrm{C}$ with some differences between zones.

in the summer and lowest in the winter. Inter-annual variation is less predictable with variation in temperature regimes reflected as 'hot-dry' and 'cool-wet' years (Poole et al., 2001).

If spatial and temporal variation is combined, three broad spatio-temporal scales may be defined (Gunderson et al., 1995 cited by Rivers-Moore et al., 2004): namely micro-scale [operating at areas $<10 \mathrm{~m}^{2}$ (site or reach) and over a time period of hours (diel)]; meso-scale [operating between $10 \mathrm{~m}^{2}$ to $10 \mathrm{~km}^{2}$ (longitudinal) and over a time period of days (seasonal)]; and macro-scale [operating at areas $>10 \mathrm{~km}^{2}$ (regional) and over a time period of years (inter-annual)]. Understanding spatial and temporal trends and variation in water temperature is necessary if the ecological responses of aquatic organisms to changes in water temperature are to be determined. Aquatic organisms, which are poikilothermic, are susceptible to changes in water temperature and it is recognised as a key environmental variable structuring aquatic communities (Arscott et al., 2001). Studies that have included water temperature as a variable indicate that spatial and temporal variation occurs in South African rivers (Box 1).

\section{The importance of water temperature in lotic ecosystems}

The importance of water temperature in river ecosystems has been recognised for some time (e.g. Whitney, 1939) and several authors have reviewed the subject (e.g. Smith, 1972; Ward, 1985; Cassie, 2006). Studies from the 1960s to 1980 s focused on the effects of thermal pollution resulting from power stations and changes in the thermal regime below impoundments, while more recently (1990s and 2000s) the potential impact of climate change on aquatic ecosystems has been driving research. Studies have broadly focused on reporting and understanding the thermal regime including water temperature modelling; documenting anthropogenic causes of thermal changes and the ecological consequences of these changes; and developing methods for estimating thermal tolerance ranges via both field experimentation and laboratory studies. In the Northern Hemisphere (Europe, North America and Japan) the thermal characteristics of lotic habitats have been reasonably well documented (Ward, $1985)$ and are considered important in influencing life histories of aquatic organisms (e.g. Brittain, 1975; Vannote and Sweeney, 1980; Elliot, 1987a; b). Thermal data for Southern Hemisphere rivers is, however, limited, with most information for Africa and Australia derived from ecological and hydrobiological studies (e.g. Appleton, 1976; Harrison and Elsworth, 1958; Oliff, 1960) with few focused studies on water temperature (e.g. Campbell, 1986; Brittain, 1991; Brittain and Campbell, 1991; Rivers-Moore and Jewett, 2004; Rivers-Moore et al., 2004; 2005). There has 
been debate on the validity of ecological concepts developed in the Northern Hemisphere to Southern Hemisphere rivers (Lake et al., 1985) including those related to the life histories of aquatic organisms and it has been suggested that environmental variability (including extreme variations in flow) overrides life history features such as synchrony (Hynes and Hynes, 1975; Campbell, 1986; McKie et al., 2004).

\section{Measuring water temperature in aquatic eco- systems - In situ measurements}

Studies measuring water temperature either record instantaneous measurements at different periods of the day or utilise water temperature loggers, which measure temperature on an hourly (or less) frequency. The latter is the more useful from an ecological perspective as it provides detail on the diurnal variation, which is important and allows for the measurement of extreme temperatures that are likely to be more ecological significant than average temperatures. For example, the presence or absence of a fish species is best predicted by the number of days a site exceeds a critical temperature threshold (Rivers-Moore et al., 2005). Water temperature has not been routinely measured in South African rivers although spot measurements of water temperature are available for many rivers (Department of Water Affairs and Forestry, 2008). This allows for some understanding of broad trends in water temperature but does not allow for an understanding of diurnal variation or temperature minimum and maximum values. More recently Rivers-Moore et al. (2004) conducted a study to determine the intra-annual thermal patterns in the main rivers of the Sabie River catchment in Mpumalanga. Other ad hoc studies have generated water temperature data for various upland rivers in the Western Cape (Dallas et al., 1998; and unpublished data), the Salt River in the southern Cape (Rivers-Moore and De Moor, unpublished data), the Great Fish River in the Eastern Cape (Rivers-Moore et al., 2006) and the Mgeni River in KwaZulu Natal (Dickens and Graham, 2006).

\section{Modelling water temperature}

Studies aimed at developing water temperature models are widespread (e.g. Smith, 1981; Mackey and Berrie, 1991) and are broadly classified into three groups: regression, stochastic and deterministic models (Cassie, 2006). The subject is reviewed extensively by Cassie (2006). Regression models include linear (e.g. Stefan and Preud'homme, 1993; Webb and Nobilis, 1997; Erickson and Stefan, 2000), multiple or logistic (nonlinear e.g. Mohseni et al., 1998; 1999) models. Simple linear models predict water temperature as a function of air temperature (mostly weekly or monthly), multiple regression models include other factors such as discharge time lag etc., while logistic models account for groundwater and evaporative cooling (Mohseni and Stefan, 1999; Webb et al., 2003). More realistic but data intensive models are the stochastic and deterministic models. Stochastic models are simpler as they require only air temperature as the input, while deterministic models use all relevant meteorological data to calculate energy components (Stefan and Sinokrot, 1993). Rivers-Moore et al. (2005) tested five different regression water temperature models using maximum daily water temperatures for the Sabie River in Mpumalanga and concluded that multiple linear regression models were the most pragmatic for simulating ecologically important water temperatures. Water temperature models are able to provide data for use in constructing thermographs for rivers (Rivers-Moore et al., 2005). Two common outputs are duration curves (percentage time versus temperature) and degree curves (hours, days), which facilitate the comparison of sites and quantify cumulative warmth at a site within a season (Essig, 1998 cited by Rivers-Moore et al., 2005).

\section{Anthropogenic factors that modify water temperature}

Several factors have been shown to modify water temperature, thereby causing a shift in the water temperature distribution, with an increase or decrease in temperature extremes; or a change in temperature variation (Table 1, next page). Elevated water temperature is more common and widely documented in the literature, although examples for South African rivers are relatively scarce. The effect of a change in water temperature may be direct including thermal discharges; or indirect including land-use changes, agricultural irrigation return-flows, flow modifications (river regulation), inter-basin water transfer, modification to riparian vegetation, and global warming. The extent to which each of these thermal modifiers affects river systems in South Africa is not known, although, it is likely that all modifiers are present within the country. Certainly, agricultural practices, flow modifications (both regulation and inter-basin water transfer) and afforestation are widespread within the country, although the extent of each is likely to vary geographically. More broadly, global warming is of significance for Southern Africa and is likely to have consequences for riverine ecosystems and the associated biota, although the severity of the effect may also vary geographically.

\section{Effects of temperature changes on physical and chemical characteristics of water}

Temperature exerts a strong influence on many physical and chemical characteristics of water including the solubility of oxygen and other gases, chemical reaction rates and toxicity, and microbial activity (Dallas and Day, 2004). Higher temperatures reduce the solubility of dissolved oxygen in water, decreasing its concentration and thus its availability to aquatic organisms. Chemical reaction rates and the toxicity of many substances (e.g. cyanide, zinc, phenol, xylene), and the vulnerability of organisms to these toxins, is intensified as temperature increases (Duffus, 1980). If the organic loading is high oxygen depletion is further accelerated by greater microbial activity at the higher temperature.

\section{Biological effects of temperature changes on aquatic organisms and aquatic ecosystems}

All organisms have a range of temperatures at which optimal growth (adult size), reproduction and general fitness occur. This is often termed the 'optimum thermal regime' (Vannote and Sweeney, 1980). Temperature outside of the 'optimum thermal regime' may effect the metabolism, growth, behaviour, food and feeding habits, reproduction and life histories, geographical distribution and community structure, movements and migrations, and tolerance to parasites, diseases and pollution; of aquatic organisms. Vannote and Sweeney's (1980) 'Thermal Equilibrium Hypothesis' ascribes a dominant role to temperature in maintaining niche differentiation in lotic assemblages and regulating large-scale patterns of species diversity and distribution (McKie et al., 2004). There is some debate on the validity of this hypothesis for Southern Hemisphere Rivers. Specifically, it is suggested that this hypothesis in its current form may not be relevant for Australia and other regions of the world where lotic 


\begin{tabular}{|c|c|}
\hline \multicolumn{2}{|r|}{$\begin{array}{l}\text { TABLE } 1 \\
\text { Anthropogenic factors that modify water temperature in lotic ecosystems }\end{array}$} \\
\hline Modifier & Characteristics and effects on aquatic organisms and riverine ecosystems \\
\hline $\begin{array}{l}\text { Thermal } \\
\text { discharges }\end{array}$ & $\begin{array}{l}\text { Sources of heated discharges include heated industrial discharge, heated cooling waters from power stations, } \\
\text { and returning irrigation waters. Effects are variable, dependent on season (Wellborn and Robinson, 1996) } \\
\text { and on the degree to which the heated effluent mixes with the receiving water (Mann, 1965). Heated indus- } \\
\text { trial discharges are frequently linked to other forms of pollution (e.g. chemical pollution) and the toxicity of } \\
\text { chemicals may be significantly increased when released in association with elevated temperatures. }\end{array}$ \\
\hline $\begin{array}{l}\text { Flow } \\
\text { modification } \\
\text { (river regulation) }\end{array}$ & $\begin{array}{l}\text { In a natural river, water temperature increases as discharge decreases (Hockey et al., 1982; Webb et al., } \\
\text { 2003), and the magnitude of diurnal variation is typically inversely proportional to flow rate (Constanz et al., } \\
\text { 1994). An alteration in the volume of discharge may affect the thermal capacity of a river and may encourage } \\
\text { higher water maxima and lower minima (Webb, 1996; Gu et al., 1998). Decreasing flow is therefore likely } \\
\text { to increase daily water temperatures, including daily maxima due to the lower corresponding depth of flow } \\
\text { (Sinokrot and Gulliver, 2000). River regulation exerts a moderating influence on the downstream thermal } \\
\text { regime, including diurnal and seasonal thermal constancy (Ward, 1982). Effects may include an increase in } \\
\text { mean water temperature and a reduction in the extent of variability between temperature extremes (Webb } \\
\text { and Walling, 1993; 1997), as well as delayed seasonal temperature maximum (Ward, 1982). The extent to } \\
\text { which an upstream impoundment modifies downstream thermal conditions depends on operational variables } \\
\text { (release depth, discharge pattern), limnological variables (retention times, stratification pattern and thermal } \\
\text { gradients) and the position of the impoundment along the longitudinal profile of the river (Ward and Stanford, } \\
\text { 1982; Palmer and O'Keeffe, 1989). Impoundments have been shown to modify the downstream biota includ- } \\
\text { ing changes in community structure of aquatic invertebrates (e.g. Petts and Greenwood, 1985; Storey et al., } \\
\text { 1991; Ogbeibu and Oribhabor, 2002) and timing and spatial pattern of fish spawning (e.g. Bok and Heard, } \\
\text { 1982; Tomasson et al., 1984; Paller and Saul, 1996; Cambray et al., 1997; King et al., 1998). Specifically, } \\
\text { reduced water temperatures resulting from a hypolimnetic discharge, delayed spawning in direct proportion } \\
\text { to the proximity to the dam (Paller and Saul, 1996), while epilimnetic releases resulted in early spawning. }\end{array}$ \\
\hline $\begin{array}{l}\text { Inter-basin water } \\
\text { transfer (IBT) }\end{array}$ & $\begin{array}{l}\text { IBT constitutes 'the transfer on water from one geographically distinct river catchment to another; or from } \\
\text { one river reach to another' (Davies et al., 1992). IBTs have been shown to have an impact on the aquatic } \\
\text { organisms of the recipient river with a shift in composition often occurring. An extensive review of IBTs } \\
\text { internationally is given in Snaddon et al. (2000). }\end{array}$ \\
\hline $\begin{array}{l}\text { Modification } \\
\text { to riparian } \\
\text { vegetation }\end{array}$ & $\begin{array}{l}\text { Riparian vegetation affects water temperature by adsorbing some of the incoming radiation, emitting long- } \\
\text { wave radiation and creating a microclimate, which in turn affects evaporation, conduction, ground and water } \\
\text { temperature (Rutherford et al., 1997). Removal of riparian vegetation exposes water to increased direct solar } \\
\text { radiation, which leads to higher temperatures, particularly during summer low flows, and greater temperature } \\
\text { ranges and fluctuations. Smaller streams with canopy-like vegetation are more likely to experience signifi- } \\
\text { cant temperature changes if the vegetation is removed, while reduction in riparian shading in larger rivers has } \\
\text { less of an effect on water temperature (Quinn et. al., 1992). Riparian vegetation is also important in influenc- } \\
\text { ing air temperatures which affect adult insects (Collier and Smith, 2000). }\end{array}$ \\
\hline $\begin{array}{l}\text { Climate change } \\
\text { and global } \\
\text { warming }\end{array}$ & $\begin{array}{l}\text { Major anthropogenic contributions to global warming include the combustion of fossil fuels and biomass, } \\
\text { nuclear fission, the burning of forests, and human and animal wastes (NWQMS, 2000). In South Africa, } \\
\text { higher air temperatures are predicted for the entire country, with January air temperatures expected to } \\
\text { increase most in the central interior and Northern Cape }\left(2.4 \text { to } 4.5^{\circ} \mathrm{C}\right) \text { and least at the coast }\left(0.5 \text { to } 1.0^{\circ} \mathrm{C}\right) \text {. } \\
\text { In general, summer rainfall is expected to increase by between } 5 \% \text { in the northern regions to } 25 \% \text { in the } \\
\text { Eastern and Southern Cape, while winter rainfall in the Western Cape is predicted to decrease by as much as } \\
25 \% \text {. The combination of rising air temperatures and decreasing rainfall in some regions is likely to lead to } \\
\text { increased water temperatures. Northern Hemisphere studies on the potential impact of global warming on } \\
\text { invertebrates (e.g. Hogg et al., 1995) and fish populations (e.g. Eaton and Scheller, 1996) indicate that changes } \\
\text { in developmental rates growth rates and emergence times may result in changes in community structure and } \\
\text { density of invertebrates. Higher temperatures may lead to a reduction in suitable habitat for cold and cool } \\
\text { water fish species (Eaton and Scheller, 1996; Keleher and Rahel, 1996) and may effectively limit the longi- } \\
\text { tudinal distribution of fish (Meisner, 1990), restrict seasonal migration patterns (Berman and Quinn, 1991), } \\
\text { and fragment populations within a catchment by isolating suitable thermal habitats (Keleher and Rahel, 1996; } \\
\text { Matthews and Zimmerman, 1990). No studies have been undertaken in South Africa, although it is likely } \\
\text { that similar scenarios may occur. The distribution ranges of the more thermally sensitive aquatic organisms, } \\
\text { including fish, may be modified with increasing water temperatures, potentially shrinking their distribu- } \\
\text { tion. This may have serious consequences for several endemic species of fish which are already under severe } \\
\text { pressure from factors such as flow modifications, land use changes, and invasion of alien fish species. The } \\
\text { Western Cape, which is predicted to have both elevated air temperatures and a } 25 \% \text { reduction in rainfall, also } \\
\text { has the highest number of endemic and threatened fish species. }\end{array}$ \\
\hline
\end{tabular}


environmental regimes (temperature and flow) are less predictable (McKie et al., 2004), such as South Africa.

Aquatic organisms may be broadly categorized as cold stenotherms (those organisms with narrow tolerance ranges in cold arctic regions); warm stenotherms (those organisms with narrow tolerance ranges in warm regions in the tropics); and eurytherms: those species with wide tolerance ranges, e.g. in temperate or sub-tropical regions (Langford, 1990). Temperature effects may be evident at the individual level through physiological and behavioural effects; the population level through development, fecundity and survival of individuals; and the community level by favouring temperature-tolerant taxa over temperature-intolerant ones leading to a shift in community structure (Mitchell, 1999).

\section{Physiological and behavioural effects at the individual level}

Aquatic organisms are very susceptible to changes in water temperature since a $10^{\circ} \mathrm{C}$ increase results in a doubling of the organism's metabolic rate (Hellawell, 1986). The increased respiration and oxygen demand, combined with reduced supply, results in significant stress to aquatic organisms. The metabolic rate of invertebrates (e.g. Eriksen, 1964) and fish (e.g. Cech et al., 1990) increase in response to elevated water temperatures. Cech et al. (1990) in a study of fish in streams of the Mediterranean region (California) of the United States, suggest that temperature (specifically the effect on metabolic rate) and dissolved oxygen (specifically the metabolic responses to hypoxia - low dissolved oxygen concentration) play a major role in determining their distribution. This region is climatically similar to the south-western Cape in South Africa. Studies on parasites and diseases have shown that fish become more susceptible to diseases when water temperature is elevated and fish are thermally stressed, and many parasites increase rapidly in response to elevated water temperatures. Water temperature plays a vital role in Schistosome (Bilharzia) transmission in permitting a suitable snail population to flourish and in controlling the length of the incubation period of the parasite in the snail (Pitchford and Visser, 1975).

Temperature (and dissolved oxygen concentrations) has been shown to modify prey behaviour in some species (e.g. Kolar and Rahel, 1993) and influence predator-prey relationships (e.g. Cockrell, 1984). It has been shown to influence the rate of feeding of invertebrates and fish, with feeding rates varying significantly at different temperatures (Kishi et al.2005), and highest feeding rates at intermediate temperatures $\left(9\right.$ to $\left.12^{\circ} \mathrm{C}\right)$, which coincided with mean summer water temperature. Some fish species also exhibit a temperature threshold below which they stop feeding or only feed sporadically (Keast, 1968 cited by Mohseni et al., 1998). Trophic interactions, such as predation, may be modified by water temperature as shown by Kishi et al. (2005) whose study highlighted the potential for trophic cascading effects resulting from changes in water temperature and provide evidence that thermal habitat alteration may affect not only thermally sensitive species like fish but also resistant species like caddis fly larvae and periphyton via indirect effects in food webs. Quinn et al. (1992) showed how changes in algal periphyton abundance and macroinvertebrate community structure were linked to increasing light and water temperature with certain taxa increasing in response to thicker algal mats while other taxa which favoured low periphyton abundance decreased. Temperature may influence movement of aquatic organisms particularly fish, which are known to utilise thermal refugia and often thermoregulate by migrating to areas of cooler water when surrounding water temperatures are outside of their preferred range or exceed their upper tolerances (e.g. Torgersen et al., 1999; Elliot, 2000; Ebersole et al., 2001; Gardner et al., 2003). Thermal refugia, which include undercut banks and overhanging vegetation (Bell, 2006), coldwater patches associated with lateral seeps, cold side-channels, floodplain tail seeps, floodplain seeps and stratified pools (Mosley, 1983; Ebersole et al., 2001) are most numerous in intact riverine systems with riparian vegetation and groundwater (Torgersen et al., 1999). Vertical stratification in pools (Matthews and Berg, 1997; Elliot, 2000; Tate et al., 2006) may result in pools acting as thermal refugia with fish migrating to cooler bottom water when surface temperatures exceed their incipient lethal limit. These bottom waters are often lower in dissolved oxygen (DO) than the surface water resulting in a trade-off between high temperatures and low DO (Matthews and Berg, 1997; Elliot, 2000).

\section{Reproduction (fecundity), development, growth and life histories at the population level}

There is a linear relationship between egg production (fecundity) in aquatic insects and adult female body size; thus any factors affecting fecundity will affect recruitment and the competitive ability of the subpopulation (Vannote and Sweeney, 1980). Temperature may influence breeding, egg incubation period (e.g. Elliot, 1972; 1987a; Harper, 1973; Humpesch, 1980; Weatherley and Ormerod, 1990; Brittain, 1991), hatching success and duration (Elliot, 1972), and the induction and termination of diapause (Ward and Stanford, 1982), and it is often the reproductive stages that are most sensitive to thermal disruption (NWQMS, 2000). Fish gonadal development and spawning may be triggered by temperature, photoperiod, water level or flooding, intra-specific interactions, and the presence of suitable spawning substrates (Lake, 1967; Jones et al., 1978 cited by Paller and Saul, 1996). Fish tend to spawn during the warmest months of year partly because rates of egg embryo and larval development are positively correlated with temperature and partly because it the time of year in temperate systems when food for larvae and juveniles is most abundant (Humphries et al., 1999). In the Northern Hemisphere several fish species spawn within 3 to $5^{\circ} \mathrm{C}$ of their critical thermal maximum. Several studies have examined the reproductive biology of fishes in South Africa (Box 2) and studies have shown that temperature is an important factor triggering spawning, with temperatures between 18 and $19^{\circ} \mathrm{C}$ triggering spawning of several of South Africa's indigenous fish species (e.g. Groenewald, 1951 cited by Tomasson et al., 1984; Wright and Coke, 1975 cited by Tomasson et al., 1984; Bok and Heard, 1982; Tomasson et al., 1984; Cambray et al., 1997; King et al., 1998).

The growth of aquatic insects has been shown to be strongly correlated with temperature in several taxa including mayflies (Markarian, 1980; Huryn, 1996), stoneflies (Harper, 1973) and isopods (Thorup, 1973). Growth rates in aquatic invertebrates have rarely been studied in South Africa (e.g. Hart, 2001) although King (1981) and King et al. (1988) suggest that the aquatic invertebrates in mountain streams of the Western Cape, South Africa have extremely slow growth rates due to the oligotrophic water. Water temperature is considered to be the most important environmental factor affecting fish growth (Marine and Cech, 2004) with growth occurring within a limited thermal range and the temperature regime determining the length of the growth season. South African studies on fish growth are mostly on fish living in impoundments or natural lakes (e.g. Bruton and Allanson, 1974; Hecht, 1980) and rarely in rivers (e.g. Baird, 


\section{Box 2 \\ Examples of fish spawning in South African rivers}

- In the Western Cape, Barbus capensis (Clanwilliam yellowfish), ascend rivers and spawn in gravel beds in relatively shallow water (Hey, 1947 cited by Cambray et al., 1997). Upstream migration occurs between September and December (Harrison, 1950 cited by Cambray et al., 1997), while gonad mass increases in August and September, reaches a maximum between October and December and decreases in January (Van Rensburg, 1966 cited by Cambray et al., 1997). Dam releases of high-flow freshes from the Clanwilliam Dam on the Olifants River in spring (October to November) corresponded with successful spawning (Cambray et al., 1997). This was linked to favourable water temperatures, with a general spring increase in water temperature. Temperature at the spawning beds was between 19.1 and $23.1^{\circ} \mathrm{C}$. In contrast, lower temperatures the following year due to late cold weather resulted in spawning bed temperatures between 16.6 to 17.5 ${ }^{\circ} \mathrm{C}$. No spawning occurred during this period (King et al., 1998). A thermal spawning threshold of $19^{\circ} \mathrm{C}$ has been proposed (King et al., 1998). In the Gouritz River system Labeo umbratus migrate upstream and spawn on the floodplain (Jackson and Coetzee, 1982). This has been observed in heavy floods in summer (Hamman and Thorne, 1982 cited by Tomasson et al., 1984). Larvae hatched after $30 \mathrm{~h}$ at $22^{\circ} \mathrm{C}$ (Mulder, $1971 \mathrm{cited}$ by Tomasson et al., 1984). Various aspects related to seasonality, spawning and life history of fish in the Western Cape are currently being investigated (Paxton, 2008).

- In the Eastern Cape, Oreochromus mossambicus, usually spawn in late November when minimum water temperatures exceeded $18^{\circ} \mathrm{C}$ (James and Bruton, 1992) while Barbus trevelyani (Border barb) requires a minimum water temperature of $18^{\circ} \mathrm{C}$ for successful induced spawning (Bok and Heard, 1982).

- In the Northern Cape, Tomasson et al. (1984) studied the reproductive biology of four indigenous cyprinids Barbus holubi (smallmouth yellowfish), Barbus kimberleyensis (largemouth yellowfish), Labeo capensis (Orange River labeo) and Labeo umbratus (moggel), in the Le Roux Dam on the Orange River. Although they studied the fish populations in the man-made lake, spawning was observed in the natural riverine section of the lake. Large Barbus spawn on gravel beds within the river channel in spring or summer, with $B$. kimberleyensis spawning 4 to 6 weeks before the more cold-tolerant $B$. holubi. Spawning in the regulated section of the dam was governed by water temperature and influenced by the effect of the hydrological regime on water temperatures, with spawning earlier when temperatures were warmer due to leases of epilimnetic water from the upstream Gariep Dam. Unseasonal hypolimnetic releases from the Gariep Dam, however, resulted in poor reproductive success. In contrast to Barbus, Labeo species spawned on newly flooded ground and spawning was asynchronous with local conditions triggering possibly localised flooding due to localised rain. L. capensis bred throughout the lake and did not exhibit a longitudinal migration while L. umbratus uses larger inflowing tributaries for spawning. Elsewhere on the upper Orange River B.holubi migrate upstream during the first spring floods and spawn over gravel beds within the river (Shortt-Smith, 1963 cited by Tomasson et al., 1984). Breeding behaviour of $B$. holubi was observed when water temperatures exceeded $18^{\circ} \mathrm{C}$ (Groenewald, 1951 cited by Tomasson et al., 1984) and fertilized eggs of $B$. halubi incubated for 3 to $8 \mathrm{~d}$ at 18 to $21.5^{\circ} \mathrm{C}$ (Le Roux, 1968 Mulder and Franke, 1973 cited by Tomasson et al., 1984).

- In Kwazulu Natal, Barbus natalensis, migrate upstream to spawn and are unable to breed in still water (Crass, 1964 cited by Tomasson et al., 1984). They spawn in clean, well circulated gravel in fast flowing water, when water temperature exceeds $19^{\circ} \mathrm{C}$ (Wright and Coke, 1975 cited by Tomasson et al., 1984).

- In neighbouring Lesotho, Oreodaimon quathlambae (Maluti minnow), is limited to the extreme upper area of the $2300 \mathrm{~km}$ Orange River system. Adults' spawn and eggs are laid amongst boulders in mid-channel which is oxygen-rich (Cambray and Meyer, 1988).

1976). Growth is often correlated with degree-days, which accounts for time and the minimum temperatures necessary for growth and is a summation of mean daily water temperature above a critical point (e.g. Hart, 1985; Markarian, 1980).

Temperature appears to be a determinant of synchrony of life history (Lake et al., 1985). Clifford (1973 cited by Campbell, 1986) suggested that life history synchrony decreased towards the equator, i.e. with latitude, with univoltine life cycles dominant in the arctic and cold temperate regions and growth restricted or completed within one part of the year. In moderate temperate regions, univoltine life cycles dominate and growth is throughout the year, while in the tropics multivoltine life cycles dominate. In high latitudes of the Northern Hemisphere, reproduction, development rates and life histories are largely synchronous and strongly seasonal (e.g. Coleman and Hynes, 1970; Brittain, 1975; Sweeney and Vannote, 1980; Macan, 1981). Short emergence periods are common (e.g. Coleman and Hynes, 1970) and the degree of synchrony in the development of nymphs (e.g. Macan, 1981) enables several species in the same genus to coexist, thereby facilitating resource partitioning. In contrast, in lower latitudes of the Northern Hemisphere emergence is longer and life cycles are less seasonal (e.g. Berner, 1950 cited by
Campbell, 1986). These differences were attributed to climatic differences, primarily higher water temperatures at the lower latitudes. In the Southern Hemisphere, Hart (1985), Campbell (1986), Hynes and Hynes (1975), McKie et al. (2004) and others have suggested that life cycles of aquatic insects are less rigid and more flexible than those found in the Northern Hemisphere and are largely asynchronous with continuous growth and long emergence periods, although there is considerable variation in life histories (Lake et al., 1985; Campbell, 1986; Huryn, 1996). The flexible life cycles are considered an adaptation to the unpredictable and highly variable climate in Southern Hemisphere regions such as Australia (Hynes and Hynes, 1975). Studies in South Africa are scarce, with information inferred from more generalist studies such as King (1981) and King et al. (1988). King et al. (1988) observed that abundance peaked in spring and late summer, while juvenile recruitment peaked in spring (November) in the Western Cape. The 'winter' communities, whose life cycles began in winter, appeared almost simultaneously with the winter rains, and predictable seasonal changes occurred at the same time each year (King, 1981). Many species emerged in summer, possibly to avoid high temperatures year (King, 1981). 


\section{Functional and structural changes at the community level}

Temperature regulates ecosystem functioning directly by influencing primary production. Studies have shown that primary production generally increases with temperature (e.g. Quinn et al., 1992; Kishi et al., 2005) and there is a shift in the dominance of algal classes from diatoms $\left(<20^{\circ} \mathrm{C}\right)$ to green algae $\left(15\right.$ to $\left.30^{\circ} \mathrm{C}\right)$ to blue-green algae $\left(>30^{\circ} \mathrm{C}\right)$ (DeNicola, 1996). Algal species diversity increases from 0 to $25^{\circ} \mathrm{C}$ and decreases at temperatures $>30^{\circ} \mathrm{C}$; while biomass increases with temperature from approximately 0 to $30^{\circ} \mathrm{C}$ and decreases at 30 to $40^{\circ} \mathrm{C}$. The degree to which algal community composition changes with thermal input depends on the initial ambient temperature, with increases in temperature in environments near 25 to $30^{\circ} \mathrm{C}$ usually causing greater changes in community structure than in environments $<25^{\circ} \mathrm{C}$ (DeNicola, 1996). Algal community structure usually recovers rapidly $(<1 \mathrm{yr})$ when temperature stress is discontinued. In many natural communities temperature does not usually limit algal biomass and primary productivity but it does set an upper limit for production when other factors are optimal (DeNicola, 1996).

Water temperature strongly influences the geographic distribution of a species (Hart, 1985; Bell, 2006) and changes in water temperature may lead to structural changes in the abundance, density, biomass, diversity and composition of aquatic communities. In the Northern Hemisphere, water temperature variability has been positively correlated with species diversity (Vannote et al., 1980) and the maximum temperature reached during the summer is thought to limit the occurrence of certain species (Vannote and Sweeney, 1980). Hawkins et al. (1997) consider summer to be a critical season for many aquatic insect populations in that much of the biological production occurs when temperatures are highest. Several studies have shown a reduction in macroinvertebrate abundance and diversity following an average temperature increase of around $7^{\circ} \mathrm{C}$ (Coutant, 1962 cited by Mann, 1965; Wellborn and Robinson, 1996; Hogg et al., 1995).

In the Northern Hemisphere, different species of fish have been shown to have different thermal niches, with groups of fish species forming three main thermal guilds - warm water, cool water and coldwater (Coutant, 1987; Magnuson et al., 1979). Studies in the Southern Hemisphere are, however, limited with some studies (e.g. Richardson et al., 1994 New Zealand) showing that fish species are able to thrive in a wide temperature range. South African freshwater fish are broadly categorized into temperate and tropical fauna with temperate fauna restricted to areas where the maximum water temperatures are generally below 25 to $28^{\circ} \mathrm{C}$ during the summer months (Skelton, 1993). Tropical fauna is restricted to areas where the water temperatures do not decline below 15 to $18^{\circ} \mathrm{C}$ during the cooler winter months (Skelton, 1993).

\section{Assessing the effects of temperature changes on aquatic organisms}

The effect of water temperature changes on aquatic organisms are assessed and monitored by direct measurement and observation in the field; and by laboratory studies, with the two methods often used in a complimentary way. Empirical data, derived from field observation, can provide useful information on the distribution of aquatic organisms. The potential problem with this method, however, is that it does not take into account microhabitat heterogeneity (Beitinger et al., 2000). Field data is often used to calculate averages such as the $7 \mathrm{~d}$ average of daily maximum temperature (Huff et al., 2005), which may be related to thermal niches. In South Africa, water temperature data are largely limited to spot measurements taken at the site with associated biotic data (e.g. Rivers Database Ewart-Smith et al., 2000) and summarised data where monthly means, maximum and minimums, etc. are given (e.g. Biobase Dallas et al., 1999). Water temperature data also exist for fish distribution records but these have not been captured into the distribution database (Bills, 2007). The utility of the two aquatic invertebrate databases in identifying thermally-sensitive taxa via calculation of the temperature ranges for different invertebrate families and selected genera or species was examined and is reported on in Dallas (2007).

Laboratory studies on the thermal tolerance of aquatic organisms are numerous particularly in the Northern Hemisphere. Effects may be assessed in terms of an organism's lethal limits (minimum and maximum), sublethal effects or behavioural avoidance preferences. For a comprehensive understanding of the effect of water temperature on aquatic organisms a combination of these methods is recommended although it is recognised that this is not always feasible.

\section{Lethal effects on aquatic organisms}

Lethal temperature is affected by several factors (Fig. 2, after Langford, 1990) including the rate of change of temperature, acclimatisation and acclimation (i.e. an organism's temperature history), duration of exposure (i.e. acute versus chronic), life history stage (e.g. eggs and larvae are often more susceptible than adult stages), multiple stresses (e.g. water quality impairment), and adaptive strategies that allow for behavioural thermoregulation or physiological adaptations. Laboratory studies include two approaches: lethal effects and critical thermal methodology. Lethal effects are determined by acute (short-term) experimental exposure to a range of temperatures in order to measure $\mathrm{LT}_{50}$ or $\mathrm{LC}_{50}$ 's (e.g. Nebeker and Lemke, 1968; De Kozlowski and Bunting, 1981). LC $_{50}$ is the temperature lethal to $50 \%$ of the test organisms, while the $\mathrm{LT}_{50}$ is the median lethal time, which is the duration eliciting $50 \%$ mortality at a specific temperature. The critical thermal methodology (CTM) is based on the exposure of an organism to a constant linear increase or decrease in temperature until a predefined sublethal but near lethal endpoint is reached. CTM is defined as: 'The arithmetic mean of the collective thermal points at which locomotory activity becomes disorganised and the animal loses its ability to escape from conditions that will probably lead to its death when heated from a previous acclimation temperature at a constant rate' (Cox, 1974 cited by Ernst et al., 1984). The CTM endpoint is the critical thermal

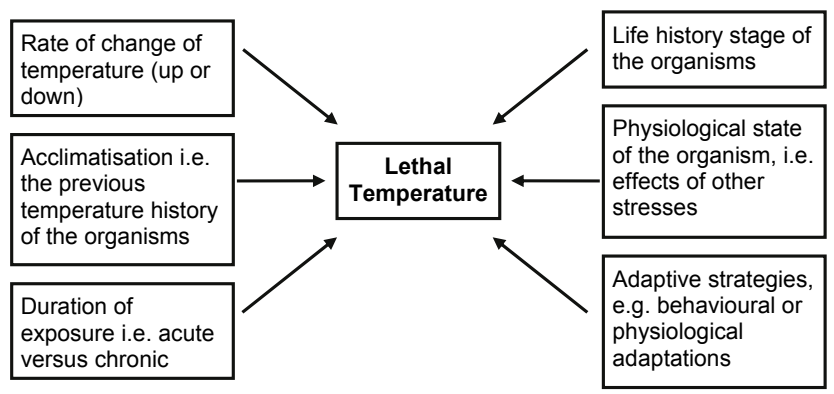

Figure 2

Factors affecting the lethal temperature for aquatic organisms (adapted from Langford, 1990) 


\begin{tabular}{|c|c|c|}
\hline \multicolumn{3}{|c|}{$\begin{array}{cc}\text { TABLE } 2 \\
\text { Guidelines and criteria for water temperature in South }\end{array}$} \\
\hline Country & Guidelines or criteria & References \\
\hline South Africa & $\begin{array}{l}\text { Guidelines are site-specific and based on the deviation from "natural" (reference) condi- } \\
\text { tions. A target water quality range is specified whereby water temperature should not } \\
\text { be allowed to vary from the background daily average water temperature considered to } \\
\text { be normal for that specific site and time of day by }>2^{\circ} \mathrm{C} \text { or by }>10 \% \text {, whichever esti- } \\
\text { mate is the more conservative. Daily temperature data are however limited and the cur- } \\
\text { rent approach used to estimate the natural distribution of temperature is by specifying } \\
\text { a monthly temperature range characterised by the } 10^{\text {th }} \text { and } 90^{\text {th }} \text { percentile temperatures. } \\
\text { Where actual data do not exist modelled temperature data for a reference site as close to } \\
\text { the resource unit of interest is used to derive the "no-effect" range. The "no-effect" and } \\
\text { "critical effect" levels thus respond to natural seasonal variation. }\end{array}$ & $\begin{array}{l}\text { DWAF, } 1996 \\
\text { Dallas et al., } \\
1998 \\
\text { Jooste and } \\
\text { Rossouw, } 2000\end{array}$ \\
\hline $\begin{array}{l}\text { Australia } \\
\text { and New } \\
\text { Zealand }\end{array}$ & $\begin{array}{l}\text { Guidelines are site-specific and based on the derivation of trigger values }\left(20^{\text {th }} \text { and } 80^{\text {th }} \text { per- }\right. \\
\text { centile). These values are based on site-specific biological effects data and are generally } \\
\text { calculated from data at a reference site. It is recommended that trigger values be developed } \\
\text { for each month (for ecosystems not characterised by large seasonal or event-scale effects) } \\
\text { or for each wet-dry season where reference data is partitioned according to specific flow } \\
\text { regimes and/or seasons. The median (maximum or minimum - depending upon whether } \\
\text { increase or decrease in temperature) daily temperature is used for comparison. Trigger } \\
\text { values may be modified depending on the management objective i.e. levels of ecosystem } \\
\text { condition. }\end{array}$ & NWQMS, 2000 \\
\hline Canada & $\begin{array}{l}\text { Guidelines are site-specific and largely based on the protection of important fish species. } \\
\text { Criteria are based on Maximum Weekly Average Temperatures (MWAT), which take into } \\
\text { account the physiological optimum temperature (usually for growth) in warmer months, } \\
\text { the survival temperature in winter months, the reproductive functions (e.g. migration } \\
\text { spawning egg incubation fry rearing) of important species during the reproductive season, } \\
\text { and overall species diversity and prevention of undesirable growths of nuisance organisms. }\end{array}$ & CCRME, 1999 \\
\hline $\begin{array}{l}\text { United } \\
\text { States }\end{array}$ & $\begin{array}{l}\text { Guidelines are numerous and often regionally focused with emphasis placed on fish popu- } \\
\text { lations. Temperature criteria generally specify a temperature threshold calculated over an } \\
\text { averaging period. Various temperature indices are used including the annual maximum } \\
\text { (the maximum hourly temperature that occurs each year), the 7-day maximum (the average } \\
\text { of the daily maximum temperature of the } 7 \text { warmest consecutive days), and the } 7 \text {-day mean } \\
\text { (MWAT) - the average of the daily mean temperature of the } 7 \text { warmest consecutive days. }\end{array}$ & $\begin{array}{l}\text { McCullough et } \\
\text { al., } 2001 \\
\text { Poole et al., } \\
\text { 2001) }\end{array}$ \\
\hline
\end{tabular}

maximum or minima CTmaximum or CTminimum (Beitinger et al., 2000) and may include loss of equilibrium and onset of muscle spasms (Beitinger et al., 2000). Survival occurs if the organism is returned to their pre-test acclimation temperature. The CTM method offers several advantages over the lethal methods in that temperature tolerances are determined without lethality, which enables tests to be performed on indigenous and possible endangered fish and the statistical analysis is relatively simple with data compared by t-tests or Analysis of Variance (ANOVA). Consideration however needs to be given to the rate of change of temperature, which needs to be fast enough to avoid acclimation but slow enough to allow an organism's internal temperature to equal water temperature. The rate of $0.3^{\circ} \mathrm{C} / \mathrm{min}$ has been recommended (Beitinger et al., 2000).

Several studies in the Northern and Southern Hemisphere have documented lethal and CTmaxima (or CTminima) for aquatic invertebrates. Many of these together with sub-lethal effects have been tabulated in Dallas (2007) although Northern Hemisphere studies are exhaustive and only selected studies are included. Lethal limits varied from $16^{\circ} \mathrm{C}$ for a North American family of Perlidae to $38.4^{\circ} \mathrm{C}$ for a freshwater prawn acclimated to $32^{\circ} \mathrm{C}$ in Mexico. In the Southern Hemisphere lethal limits varied from $21.9^{\circ} \mathrm{C}$ for a leptophlebiid mayfly to $32.4^{\circ} \mathrm{C}$ for a hydrobid snail (New Zealand studies). Mean CTM varied from $31.5^{\circ} \mathrm{C}$ for a North America perlid to $40.7^{\circ} \mathrm{C}$ for freshwater prawns. No
Southern Hemisphere studies using traditional CTM were noted. Information on temperature tolerances of North American fish is numerous and approximately 80 studies provide tolerance data (see Beitinger et al., 2000 for a review). Information on the tolerance ranges of Southern Hemisphere fish is less plentiful (e.g. Richardson et al., 1994), while South African studies on the temperature tolerance of freshwater fish is scarce.

\section{Sublethal effects}

Sublethal (chronic) effects include those on reproduction, spawning, egg incubation and hatchability, development and growth, survival of fry, and emergence success, as well as sublethal physiological effects. The duration of exposure is important in assessing sublethal effects. Two common measures of chronic exposure are the maximum weekly average temperature (MWAT) and the maximum weekly maximum temperature (MWMT). Many studies have examined egg incubation and hatchability rates for aquatic insects (Elliot, 1972; Harper, 1973; Humpesch, 1980; Weatherley and Ormerod, 1990; Brittain, 1991) and fish (e.g. Brungs, 1971; Crisp, 1990; Evans and Petts, 1997), while others have examined growth rates (e.g. Thorup, 1973; Markarian, 1980; Vannote and Sweeney, 1980; Coutant, 1987; Richardson et al., 1994) and emergence success (e.g. Nebeker, 1971a; b; 1972; Nordlie and Arthur, 1981). Studies on 
the physiological effects of modifications to water temperature are often linked to metabolic rates (e.g. Eriksen, 1964; Beamish, 1981; Cech et al., 1990) and oxygen consumption (e.g. Nebeker et al., 1996).

\section{Behavioural preferences and avoidance}

Studies on the behavioural effects have primarily been undertaken on fish (e.g. Cincotta and Stauffer, 1984) with fewer studies conducted on aquatic invertebrates (e.g. Gerald and Spezzano, 2005). Thermal gradient tanks have been used to determine temperature preferences (Cherry and Cairns, 1982; Boubee et al., 1991; Richardson et al., 1994). This technique involves the establishment of a temperature gradient that is then used to evaluate the temperatures preferred or avoided by various organisms. The method facilitates the determination of the effects of gradual temperature changes and allows ontogenetic shifts in temperature preferences to be calculated. Boubee et al. (1991) showed experimentally that the final preferred temperature of Galaxias maculates resident in New Zealand is about $20^{\circ} \mathrm{C}$ and temperatures above $29.5^{\circ} \mathrm{C}$ were totally avoided.

\section{Water temperature guidelines for the protection of aquatic ecosystems}

An examination of the guidelines for water temperature in aquatic ecosystems highlights the importance of understanding natural spatial and temporal variability in water temperature. Identification of appropriate temperature criteria to protect aquatic organisms is complicated by the highly variable nature of water temperature in rivers, coupled with the variable temperature requirements of aquatic organisms. Guidelines stress that no single temperature or thermal regime would be suitable for all seasons, all parts of a country, all river zones or all species. The characteristics of temperature regimes relevant to temperature criteria (Sullivan et al., 2000) include temperature thresholds that reflect biological effects (acute sublethal); temperature fluctuation characteristic (maximum mean minimum fluctuation); and averaging period (instantaneous maximum $7 \mathrm{~d}$ average monthly seasonal average). Temperature criteria typically have two key elements: a threshold temperature that signals when adverse biological response is likely to occur; and an averaging period that indexes the duration of exposure likely to trigger that response (Sullivan et al., 2000). The combination of the threshold temperature and the duration of exposure to that temperature are an expression of the risk imposed by the environmental temperature to the targeted species. Table 2 provides a brief overview of the current guidelines developed in South Africa and elsewhere including Australia and New Zealand the United States and Canada. No appropriate references were located for the European Union.

\section{Conclusions}

This overview highlights the complexity of water temperature in the aquatic environment, the importance of understanding the spatial and temporal variability in water temperature, and the variable responses of aquatic organisms to thermal stress. Anthropogenic modifiers of the thermal regime, including heated discharges, flow modifications, riparian vegetation removal and global climate change, present ongoing threats to aquatic ecosystems. South Africa is a country already stressed by scarcity of water. The risk of increasingly harsh conditions caused by greater water demands and climate change, reflected as higher air temperatures and lower rainfall, accentuates the need for a greater understanding of the thermal conditions in aquatic ecosystems in South Africa and the requirements and triggers of the associated aquatic biota. Whilst Northern Hemisphere information on temperature is plentiful, this overview has identified the huge gap that exists in temperature-related data in South Africa. Without baseline data on water temperature and the thermal requirements of aquatic organisms, it is extremely difficult to adequately manage aquatic ecosystems. It is thus critical that this knowledge gap be filled through a comprehensive and integrated applied research programme.

Such a programme has recently been initiated in South Africa (Dallas and Rivers-Moore, 2008) with the focus on lotic ecosystems, since these systems are subject to flow regulation and water abstraction to a much greater degree than lentic systems. The persistence of these ecosystems is more likely to be achieved through a better understanding of water temperature patterns and processes. Emphasis will be placed on the collection of long term data, which are necessary for extracting principles on water temperature relevant to South Africa. These will in turn inform policy. Research has indicated that there are likely to be significant differences between Northern and Southern Hemisphere aquatic thermal regimes (Dallas, 2007; RiversMoore, 2007). Thus, Northern Hemisphere practices cannot be blindly applied to management issues in Southern African rivers. It is recognised that only through a foundation of fundamental research linking water temperatures and biotic response, will the water temperature requirements for the ecological Reserve be met. The exact nature of these differences will only truly be understood through a series of carefully constructed in situ and ex situ projects linking biotic response to thermal triggers. The usefulness of these data will be further enhanced through a more complete spatial understanding of water temperatures and a series of scenario analyses, based on temperature simulations using a suitable water temperature model.

\section{Acknowledgments}

The Water Research Commission provided funding for this research consultancy - thanks to Dr Steve Mitchell and Dr Stanley Liphadzi for facilitation of this research.

\section{References}

ALLANSON B (1961) Investigations into the ecology of polluted inland waters in the Transvaal. Hydrobiol. 18 1-76.

APPLETON C (1976) Observations on the thermal regime of a stream in the eastern Transvaal with reference to certain aquatic Pulmonata. S. Afr. J. Sci. 72 20-23.

ARSCOTT D, TOCKNER K and WARD J (2001) Thermal heterogeneity along a braided floodplain river (Tagliamento River, northeastern Italy). Can. J. Fish. Aquat. Sci. 58 2359-2373.

BAIRD D (1976) Aspects of the growth and reproduction of Labeo capensis in the Caledon River. J. Limnol. Soc. South. Afr. 2 25-28.

BEAMISH F (1981) Swimming performance and metabolic rate of three tropical fishes in relation to temperature. Hydrobiol. 83 245-254.

BEITINGER T, BENNET W and McCAULEY R (2000) Temperature tolerances of North American freshwater fishes exposed to dynamic changes in temperature. Environ. Biol. Fish. 58 237-275.

BELL J (2006) The Assessment of Thermal Impacts on Habitat Selection Growth Reproduction and Mortality in Brown Trout (Salmo trutta L.): A Review of the Literature Rep. No. EPA GRANT \#WS 97512701-0. Applied Ecological Services Inc Minnesota.

BERMAN C and QUINN T (1991) Behavioural thermoregulation and homing by spring chinook salmon (Oncorhynchus tshawytscha Walbaum) in the Yakima River. J. Fish Biol. 39 301-321. 
BILLS R (2007) Personal communication. South African Institute of Aquatic Biodiversity (SAIAB) Grahamstown, South Africa.

BOK A and HEARD H (1982) Induced spawning of Barbus trevelyani (Pisces Cyprinidae). S. Afr. J. Wild. Res. 12 106-108.

BOUBEE J, SCHICKER K and STANCLIFF A (1991) Thermal avoidance in inanga Galaxias maculatus (Jenyns) from the Waikato River New Zealand. N. Z. J. Mar. Freshwater Res. 25 177-180.

BRITTAIN J (1975) The life cycle of Baetis macani Kimmins (Ephemeridae) in a Norwegian mountain biotope. Ent. Scan. 6 47-51.

BRITTAIN J (1991) Effect of temperature on egg development in the Australian stonefly genus Austrocercella Illies (Plecoptera: Notonemouridae). Aust. J. Mar. Freshwater Res. 42 107-114.

BRITTAIN J and CAMPBELL I (1991) The effect of temperature on egg development in the Australian mayfly genus Coloburiscoides (Ephemeroptera: Coloburiscidae) and its relationship to distribution and life history. J. Biogeog. 18 231-235.

BRUNGS W (1971) Chronic effects of constant temperature on the fathead minnow, Pimephales promelas rafinesqe. American Fisheries Society 100 659-664.

BRUTON M and ALLANSON B (1974) The growth of Tilapia mossambica Peters (Pisces: Cichlidae) in Lake Sibaya, South Africa. J. Fish Biol. 6 701-715.

CAISSIE D (2006) The thermal regime of rivers: a review. Fresh. Biol. 51 1389-1406.

CAMBRAY J, KING J and BRUWER C (1997) Spawning behaviour and early development of the Clanwilliam Yellowfish (Barbus capensis: Cyprinidae) linked to experimental dam releases in Olifants River South Africa. Reg. Rivers Res. Manag. 13 579-602.

CAMPBELL I (1986) Life histories of some Australian Siphlonurid and Oligoneurid mayflies (Insecta: Ephemeroptera). Aust. J. Mar. Freshwater Res. 37 261-288.

CCREM (1999) A Protocol for the Derivation of Water Quality Guidelines for the Protection of Aquatic Life. Canadian Council of Ministers of the Environment, Canada.

CECH J, MITCHELL S, CASTLEBERRY D and MCENROE M (1990) Distribution of California stream fishes: influence of environmental temperature and hypoxia. Environ. Biol. Fish. 29 95-105.

CHERRY D and CAIRNS J (1982) Biological monitoring - Part V: preference and avoidance studies. Water Res. 16 263-301.

CHUTTER F (1970) Hydrobiological studies in the catchment of Vaal Dam South Africa. Part 1: River zonation and the benthic fauna. Int. Rev. ges Hydrob. 55 445-494.

CINCOTTA D and STAUFFER J (1984) Temperature preference and avoidance studies of six North American freshwater fish species. Hydrobiol. 109 173-177.

CLARK E, WEBB B and LADLE M (1999) Microthermal gradients and ecological implications in Dorset rivers. Hydrol. Process. 13 423-438.

COCKRELL B (1984) Effects of temperature and oxygenation on predator-prey overlap and prey choice of Notonecta glauca. J. Anim. Ecol. 53 519-532.

COLEMAN M and HYNES H (1970) Life histories of some Plecoptera and Ephemeroptera in a southern Ontario stream. Can. J. Zool. 48 1333-1339.

COLLIER K and SMITH B (2000) Interactions of adult stoneflies (Plecoptera) with riparian zones. I Effects of air temperature and humidity on longevity. Aquat. Insects 22 275-284.

CONSTANZ J, THOMAS C and ZELLWEGER G (1994) Influence if diurnal variations in stream temperature on streamflow loss and groundwater recharge. Water Resour. Res. 30 3253-3264.

COUTANT C (1987) Thermal preference: when does an asset become a liability? Environ. Biol. Fish. 18 161-172.

CRISP D (1990) Water temperature in a stream gravel bed and implications for salmonid incubation. Freshwater Biol. 23 601-612.

DALLAS H (2007) The Effect of Water Temperature on Aquatic Organisms: A Review of Knowledge and Methods for Assessing Biotic Responses to Temperature. WRC Report for Project K8-690. Water Research Commission, Pretoria, South Africa.

DALLAS H and DAY J (2004) The Effect of Water Quality Variables on Aquatic Ecosystems: A Review. WRC Technical Report No. 224/04, Water Research Commission, Pretoria, South Africa.

DALLAS H and RIVERS-MOORE N (2008) Water Temperatures and the Ecological Reserve. WRC Project No. K5/1799. Water Research Commission, Pretoria, South Africa.

DALLAS H, DAY J, MUSIBONO D and DAY E (1998) Water quality for aquatic ecosystems: tools for evaluating regional guidelines. WRC Technical Report No. 626/1/98. Water Research Commission, Pretoria, South Africa.

DALLAS H, JANSSENS M and DAY J (1999) An aquatic macroinvertebrate and chemical database for riverine ecosystems. Water $S A \mathbf{2 5}$ $1-8$

DAVIES B, THOMS M and MEADOR M (1992) Viewpoint: an assessment of the ecological impacts of inter-basin water transfers and their threats to river basin integrity and conservation. Aquat. Cons. Mar. Fresh. Ecosys. 2 325-349.

DENICOLA D (1996) Periphyton responses to temperature at different ecological levels. In: Algal Ecology in Freshwater Benthic Ecosystems. Academic Press New York.

DEPARTMENT OF WATER AFFAIRS AND FORESTRY (2008) Water Affairs Water Quality Monitoring Points. (http://www.dwaf. gov.za/IWQS/wms/WebInventory/Others/PointInventory.HTML).

DICKENS C and GRAHAM M (2006) In connection with the ecological impacts of reverse hydrograph water releases from Albert Falls Dam on in-stream processes. Water Research Commission, Pretoria, South Africa.

DUFFUS J (1980) Environmental Toxicology. Edward Arnold Publishers, London.

DWAF (1996) South African Water Quality Guidelines Volume 7: Aquatic Ecosystems. Department of Water Affairs and Forestry, Pretoria, South Africa.

EATON J and SCHELLER R (1996) Effects of climate warming on fish thermal habitat in streams of the United States. Limnol. Oceonogr. 41 1109-1115.

EBERSOLE J, LISS W and FRISSELL C (2001) Relationship between stream temperature thermal refugia and rainbow trout Oncorhynchus mykiss abundance in arid-land streams in the northwestern, United States. Ecol. Fresh. Fish 10 1-10.

EBERSOLE J, LISS W and FRISSELL C (2003) Cold water patches in stream: Physicochemical characteristics and the influence of shading. J. Amer. Wat. Res. Ass. 39 355-368.

ELLIOTT J (1972) Effect of temperature on the time of hatching in Baetis rhodani (Ephemeroptera: Baetidae). Oecologia 9 47-51.

ELLIOTT J (1987a) Egg hatching and resource partitioning in stoneflies: The six British Leuctra spp. (Plecoptera: Leuctridae). J. Animal Ecol. 56 415-426.

ELLIOTT J (1987b) Temperature-induced changes in the life cycle of Leuctra nigra (Plecoptera: Leuctridae) from a Lake District stream. Fresh. Biol. 18 177-184.

ELLIOTT J (2000) Pools as refugia for brown trout during two summer droughts: trout responses to thermal and oxygen stress. J. Fish Biol. 56 938-948.

ERICKSON T and STEFAN H (2000) Linear air/water temperature correlations for streams during open water periods. J. Hydrol. Eng. 5 317-321.

ERIKSEN C (1964) Evidence of a spring rise in metabolic rate in the burrowing mayfly Ephemera simulans Walker. Hydrobiol. $\mathbf{2 3}$ 506-510.

ERNST M, BEITINGER T and STEWART K (1984) Critical maxima of nymphs of three plecoptera species from an Ozark foothill stream. Freshwater Invertebrate Biol. 3 80-85.

EVANS E and PETTS G (1997) Hyperheic temperature patterns within riffles. J. Hydrol. Sci. 42 199-213.

EWART-SMITH J, DALLAS H and JANSSENS M (2000) Rivers Database: Version 1A User Manual Rep. No. 11. Institute for Water Quality Studies, Department of Water Affairs and Forestry, Pretoria, South Africa.

GARDNER B, SULLIVAN P and LEMBOR A (2003) Predicting stream temperatures: geostatistical model comparison using alternative distance metrics. Can. J. Fish. Aquat. Sci. 60 344-351.

GERALD G and SPEZZANO C (2005) The influence of chemical cues and conspecific density on the temperature selection of a freshwater snail (Melanoides tuberculata). Journal of Thermal Biology 20 237-245.

GU R, MONTGOMERY S and AUSTIN T (1998) Quantifying the 
effects of stream discharge on summer river temperature. J. Hydrol. Sci. 43 885-904.

HARPER P (1973) Life histories of Nemouridae and Leuctridae in Southern Ontario (Plecoptera). Hydrobiol. 41 309-356.

HARRISON A (1965) River zonation in Southern Africa. Arch. Hydrobiol. 61 380-386.

HARRISON A and ELSWORTH J (1958) Hydrobiological studies on the Great Berg River Western Cape province. Part I: General description chemical studies and main features of the flora and fauna. Trans. Royal Soc. South Africa 35 125-226.

HART R (1985) Seasonality of aquatic invertebrates in low-latitude and Southern Hemisphere inland waters. Hydrobiol. 25 151-178.

HART R (2001) Rapid estimation of in situ growth rates of Caridina nilotica (Crustacea: Decapoda) in Lake Victoria: Description and pilot application of a simple field-compatible technique. Limnology and Oceanography 46 692-698.

HAWKINS C, HIGUE J, DECKER L and FEMINELLA J (1997) Channel morphology water temperature and assemblage structure of stream insects. J. North Am. Benthol. Soc. 16 728-749.

HECHT T (1980) A comparison between otolith and scale methods of ageing and the growth of Sarotherodon mossambicus (Pisces: Cichlidae) in a Venda impoundment (Southern Africa). S. Afr. J. Zool. 15 222-228.

HELLAWELL J (1986) Biological Indicators of Freshwater Pollution and Environmental Management. Elsevier Applied Science, London.

HOCKEY J, OWENS I and TAPPER N (1982) Empirical and theoretical models to isolate the effect of discharge on summer water temperatures in the Hurunui river. J. Hydrol. 21 1-12.

HOGG I, WILLIAMS D, EADIE J and BUTT S (1995) The consequences of global warming for stream invertebrates: a field simulation. J. Thermal Biol. 20 199-206.

HOPKINS C (1971) The annual temperature regime of a small stream in New Zealand. Hydrobiol. 37 397-408.

HUFF D, HUBLER S and BORISENKO A (2005) Using field data to estimate the realised thermal niche of aquatic vertebrates. N. Am. J. Fish. Manage. 25 346-360.

HUMPESCH U (1980) Effect of temperature on the hatching time of eggs of five Ecdyonurus spp. (Ephemeroptera) from Austrian streams and English streams rivers and lakes. J. Anim. Ecol. 49 317-333.

HUMPHRIES P, KING A and KOEHN J (1999) Fish flows and flood plains: links between freshwater fishes and their environment in the Murray-Darling system Australia. Environ. Biol. Fish. 56 129-151.

HURYN A (1996) Temperature-dependent growth and life cycle of Deleatidium (Ephemeroptera: Leptophlebiidae) in two high-country streams in New Zealand. Fresh. Biol. 36 351-361.

HYNES H and HYNES M (1975) The life histories of many of the stoneflies (Plecoptera) of South-eastern Mainland Australia. Aust. J. Mar. Freshwater Res. 26 113-153.

JACKSON P and COETZEE P (1982) Spawning behaviour of Labeo umbratus (Smith) (Pisces: Cyprinidae). S. Afr. J. Sci. 78 293-295.

JAMES N and BRUTON M (1992) Alternative life-history traits associated with reproduction in Orechromis mossambicus (Pisces: Cichlidae) in small water bodies of the eastern Cape South Africa. Environ. Biol. Fish. 34 379-392.

JOOSTE S and ROSSOUW J (2002). Hazard-Based Water Quality EcoSpecs For The Ecological Reserve In Fresh Surface Water Resources Rep. No. N/0000/REQ0000. Institute for Water Quality Studies Department of Water Affairs and Forestry, Pretoria, South Africa.

KELEHER C and RAHEL F (1996) Thermal limits to salmonid distributions in the rocky mountain region and potential habitat loss due to global warming: A Geographic Information System (GIS) approach. Trans. Amer. Fish. Soc. 125 1-13

KING J (1981) The distribution of invertebrate communities in a small South African river. Hydrobiol. 83 43-65.

KING J, CAMBRAY J and IMPSON N (1998) Linked effects of damreleased floods and water temperature on spawning of the Clanwilliam yellowfish Barbus capensis. Hydrobiol. 384 245-265.

KING J, DAY J, HURLEY P, HENSHALL-HOWARD M and DAVIES B (1988) Macroinvertebrate communities and environment in a southern African mountain stream. Can. J. Fish. Aquat. Sci. 45
2168-2181.

KISHI D, MURAKAMI M, NAKANO S and MAEKAWA K (2005) Water temperature determines strength of top-down control in a stream food web. Freshwater Biol. 50 1315-1322.

KOLAR C and RAHEL F (1993) Interaction of a biotic factor (predator presence) and an abiotic factor (low oxygen) as an influence on benthic invertebrate communities. Oecologia 95 210-219.

LAKE J (1967) Rearing experiments with five species of Australian freshwater fishes: I. Inducement to spawning. Aust. J. Mar. Freshwater Res. 18 137-154.

LAKE P, BARMUTA L, BOULTON A, CAMPBELL I and CLAIR R (1985) Australian streams and northern hemisphere stream ecology: comparisons and problems. Proc. Ecol. Soc. Aust. 14 61-82.

LANGFORD T (1990) Ecological Effects of Thermal Discharges. Elsevier Applied Science London and New York.

MACKEY A and BERRIE A (1991) The prediction of water temperatures in chalk streams from air temperatures. Hydrobiol. $\mathbf{2 1 0}$ 183-189.

MADIKIZELA B and DYE A (2003) Community composition and distribution of macroinvertebrates in the Umzimvubu River South Africa: a pre-impoundment study. Afr. J. Aquat. Sci. 28 137-149.

MAGNUSON J, CROWDER L and MEDVICK P (1979) Temperature as an ecological resource. Am. Zool. 19 331-343.

MANN K (1965) Heated effluents and their effects on the invertebrate fauna of rivers. Proc. Soc. Water Treat. Exam. 14 45-53.

MARINE K and CECH J (2004) Effects of high water temperature on growth smoltification and predator avoidance in juvenile Sacramento River Chinook salmon. N. Am. J. Fish. Manage. 24 198-210.

MARKARIAN R (1980) A study of the relationship between aquatic insect growth and water temperature in a small stream. Hydrobiol. 75 81-95.

MATTHEWS H and BERG N (1997) Rainbow trout responses to water temperature and dissolved oxygen stress in two southern California stream pools. J. Fish Biol. 50 50-67.

MATTHEWS W and ZIMMERMAN E (1990) Potential effects of climate change on native fish of the southern Great Plains and Southwest. Fish. 15 26-32.

McKIE B, CRANSTON P and PEARSON R (2004) Gondwanan mesotherms and cosmopolitan eurytherms: effects of temperature on the development and survival of Australian Chironomidae (Diptera) from tropical and temperate populations. Mar. Freshwater Res. 55 759-767.

MEISNER J (1990) Potential loss of thermal habitat for brook trout due to climatic warming in two Southern Ontario streams. Trans. Am. Fish. Soc. 119 282-291.

MITCHELL S (1999) A simple model for estimating mean monthly stream temperatures after riparian canopy removal. Environ. Manage. 24 77-83.

MOHSENI O, ERICKSON T and STEFAN H (1999) Sensitivity of stream temperatures in the United States to air temperatures projected under a global warming scenario. Water Resour. Res. 35 3723-3733.

HSENI O and STEFAN H (1999) Stream temperature/air temperature relationship: a physical interpretation. J. Hydrol. 218 128-141.

MOHSENI O, STEFAN H and ERICKSON T (1998) A nonlinear regression model for weekly stream temperatures. Water Resour. Res. 34 2685-2692.

MOSLEY M (1983) Variability of water temperatures in the braided Ashley and Rakaia rivers. N. Z. J. Mar. Freshwater Res. 17 331-342.

NEBEKER A (1971a) Effect of water temperature on nymphal feeding rate emergence and adult longevity of the stonefly Pteronarcys dorsata. J. Kansas Entomol. Soc. 44 21-26.

NEBEKER A (1971b) Effect of high winter water temperatures on adult emergence of aquatic insects. Water Res. 5 77-783.

NEBEKER A (1972) Effect of low oxygen concentration on survival and emergence of aquatic insects. Trans. Am. Fish. Soc. 4 675-679.

NEBEKER A and LEMKE A (1968) Preliminary studies on the tolerance of aquatic insects to heated water. J. Kansas Entomol. Soc. 41 413-418.

NEBEKER A, ONJUKKA S, STEVENS D and CHAPMAN G (1996) Effect of low dissolved oxygen on aquatic life stages of the caddisfly Clistoronia magnifica (Limnephilidae). Arch. Environ. Contam. 
Toxicol. 31 453-458.

NORDLIE K and ARTHUR J (1981) Effect of elevated water temperature on insect emergence in outdoor experimental channels. Environ. Pollut. 25 53-65.

NWQMS (2000) National water quality management strategy: Australian and New Zealand Guidelines for Fresh and Marine Water Quality Rep. No. 4A. Australian and New Zealand Environment and Conservation Council and Agriculture and Resource Management Council of Australia and New Zealand Australia.

OGBEIBU A and ORIBHABOR B (2002) Ecological impact of river impoundment using benthic macro-invertebrates as indicators. Water Res. 36 2427-2436.

OLIFF W (1960) Hydrobiological studies on the Tugela System Part II: Organic pollution in the Bushmans River. Hydrobiol. 16 137-196.

PALLER M and SAUL B (1996) Effects of temperature gradients resulting from reservoir discharge on Dorsoma cepedianum spawning in the Savannah River. Environ. Biol. Fish. 45 151-160.

PAXTON (2008) Personal communication. Freshwater Research Unit, University of Cape Town, South Africa.

PALMER R AND O'KEEFFE J (1989) Temperature characteristics of an impounded river. Archiv. Hydrobiol. 116 471-485.

PETTS G and GREENWOOD M (1985) Channel changes and invertebrate faunas below Nant-Y-Moch dam River Rheidol Wales UK. Hydrobiol. 122 65-80.

PITCHFORD R and VISSER P (1975) The effect of large dams on river water temperature below the dams with special reference to bilharzia and the Verwoerd Dam. S. Afr. J. Sci. 71 212-213.

POOLE G and BERMAN C (2001) An ecological perspective on instream temperature: natural heat dynamics and mechanisms of human-caused thermal degradation. Environ. Manage. 27 787-802.

POOLE G, RISLEY J and HICKS M (2001) Issue paper 3 - Spatial and temporal patterns of stream temperature Rep. No. Issue Paper 3. EPA-910-D-01-003 United States Environmental Protection Agency. United States Environmental Protection Agency.

QUINN J, WILLIAMSON R, SMITH R and VICKERS M (1992) Effects of riparian grazing and channelisation on streams in Southland New Zealand. 2. Benthic invertebrates. N. Z. J. Mar. Freshwater Res. 26 259-273.

RICHARDSON J, BOUBEE J and WEST D (1994) Thermal tolerance and preference of some native New Zealand freshwater fish. N. Z. J. Mar. Freshwater Res. 28 399-407.

RIVERS-MOORE N and JEWITT G (2004) Intra-annual thermal patterns in the main rivers of the Sabie Catchment Mpumalanga South Africa. Water SA 30 445-452.

RIVERS-MOORE N, JEWITT G and WEEKS D (2005) Derivation of quantitative management objectives for annual instream water temperatures in Sabie River using a biological index. Water SA 31 473-480.

RIVERS-MOORE N, JEWITT G, WEEKS D and O'KEEFFE J (2004) Water Temperature and Fish Distribution in the Sabie River System: Towards the Development of an Adaptive Management Tool. WRC Report No. 1065/1/04. Water Research Commission, Pretoria, South Africa.

RIVERS-MOORE N, MOOR F.D, MORRIS C and O'KEEFFE J (2006) Effect of flow variability modification and hydraulics on invertebrate communities in the Great Fish River (Eastern Cape province South Africa) with particular reference to critical hydraulic thresholds limiting larval densities of Simulium chutteri Lewis (Diptera Simuliidae). River Res. Applic. 23 201-222.

ROOS J and PIETERSE A (1994) Light temperature and flow regimes of the Vaal River at Balkfontein South Africa. Hydrobiol. 277 1-15.

RUTHERFORD J, BLACKETT S, BLACKETT C, SAITO L and DAVIES-COLLEY R (1997) Predicting the effects of shade on water temperature in small streams. N. Z. J. Mar. Freshwater Res. 31 707-721.

SINOKROT B and GULLIVER J (2000) In-stream flow impact on river water temperatures. J. Hydraul. Res.38 339-349.
SKELTON P (1993) A Complete Guide to the Freshwater Fishes of Southern Africa. Southern Book Publishers, Johannesburg.

SMITH K (1972) River water temperatures - An environmental review. Scottish Geographical Magazine 88 211-220.

SMITH K (1981) The prediction of river water temperatures. Hydrobiol. Sci. Bull. 26 19-32.

SNADDON C, DAVIES B and WISHART M (2000) A global overview of inter-basin water transfer schemes: ecological socio-economic and socio-political implications and recommendations for their management. WRC Report No. TT 120/00. Water Research Commission, Pretoria, South Africa.

STEFAN H and PREUD'HOMME E (1993) Stream temperature estimation from air temperature. Water Resour. Bull. 29 27-45.

STEFAN H and SINOKROT B (1993) Projected global climate change impact on water temperatures in five north central U.S streams. Clim. Change 24 353-381.

STOREY A, EDWARD D and GAZEY P (1991) Recovery of aquatic macroinvertebrate assemblages downstream of the canning dam Western Australia. Reg. Rivers Res. Manage. 6 213-224.

SULLIVAN K, MARTIN D, CARDWELL R, TOLL J and DUKE S (2000) An Analysis of the Effects of Temperature on Salmonids of the Pacific Northwest with Implications for Selecting Temperature Criteria. Sustainable Ecosystems Institute, Portland, Oregon, USA.

TATE K, LANCASTER D and LILE D (2006) Assessment of thermal stratification within stream pools as a mechanism to provide refuge for native trout in hot arid rangelands. Environ. Mon. Assess. 124 289-300.

THORUP J (1973) Interpretation of growth-curves for animals from running waters. Verh. Internat. Verein. Limnol. 18 1512-1520.

TOMASSON T, CAMBRAY J and JACKSON P (1984) Reproductive biology of four large riverine fishes (Cyprinidae) in a man-made lake Orange River South Africa. Hydrobiol. 112 179-195.

TORGERSEN C, PRICE D, LI H and MCINTOSH B (1999) Multiscale thermal refugia and stream habitat associations of chinook salmon in north-Eastern Oregon. Ecolog. App. 9 301-319.

VANNOTE R and SWEENEY B (1980) Geographic analysis of thermal equilibria: A conceptual model for evaluating the effect of natural and modified thermal regimes on aquatic insect communities. Am. Nat. 115 667-695.

WARD J (1982) Ecological aspects of stream regulation: responses in downstream lotic reaches. Water Pollut. Manage. Rev. 2 1-26.

WARD J (1985) Thermal characteristics of running waters. Hydrobiol. 125 31-46.

WARD J and STANFORD J (1982) Thermal responses in the evolutionary ecology of aquatic insects. Ann. Rev. Entomol. 27 97-117.

WEATHERLEY N and ORMEROD S (1990) Forests and the temperature of upland streams in Wales: a modelling exploration of the biological effects. Freshwater Biol. 24 109-122.

WEBB B (1996) Trends in stream and river temperature. Hydrol. Process. 10 205-226.

WEBB B, CLACK P and WALLING D (2003) Water-air temperature relationships in a Devon river system and the role of flow. Hydrol. Process. 17 3069-3084.

WEBB B and NOBILIS F (1997) Long-term perspective on the nature of the air-water temperature relationship: a case study. Hydrol. Process. 11 137-147.

WEBB B and WALLING D (1993) Temporal variability in the impact of river regulation on thermal regime and some biological implications. Freshwater Biol. 29 167-182.

WEBB B and WALLING D (1997) Complex summer water temperature behaviour below a UK regulating reservoir. Reg. Rivers Res. Manage. 13 463-477.

WELLBORN G and ROBINSON J (1996) Effects of a thermal effluent on macroinvertebrates in a central Texas reservoir. Am. Midl. Nat. 136 110-120.

WHITNEY R (1939) The thermal resistance of mayfly nymphs from ponds and streams. J. Exp. Biol. 16 374-385. 